\title{
PERCEIVED STRESS AND SOCIAL SUPPORT AS PREDICTORS OF SUBJECTIVE WELL-BEING AMONG UNIVERSITY STUDENTS IN NIGERIA
}

\author{
Чінело Хелен ОҐВУЧЕ, Она КААЕБ, Аенніс РЕ ООАЖКО-ГОВЕ \\ СПРИЙНЯТТЯ СТРЕСУ І СОЦІАЛЬНОÏ ПІДТРИМКИ \\ ЯК ПОКАЗНИКИ СУБ'ЄКТИВНОГО БЛАГОПОЛУЧЧЯ \\ СЕРЕД СТУДЕНТІВ УНІВЕРСИТЕТУ НІГЕРІї
}

\section{Introduction}

The term 'subjective well-being' (SWB), introduced by Diener (1984), is often used interchangeably with - or in order to avoid the ambiguous meaning - the term 'happiness'. The SWB literature covers studies that have used such diverse terms as happiness, hedonic level, satisfaction with life, moral, and positive affect (Relojo \& dela Rosa, 2017). The first broad review of happiness research was conducted by Wilson (1967) and concluded that: 'the happy person emerges as a young, healthy, well-educated, well-paid, extroverted, optimistic, worryfree, religious, married person, with high selfesteem, high job moral, modest aspirations, of either sex and of a wide range of intelligence'.

Zarbova and Karabeliova (2018) identified a correlation between the subjective perception for the levels of stress and well-being within a six-month period and a correlation with selfperception for feeling of happiness and life satisfaction. A pilot survey was conducted with a sample of 90 respondents, 36 men and 54 women, aged 26-64 $(M=42.52 ; S D=8.89)$, 20 people live alone and 70 have a partner. Participants work as pilots, air traffic controllers, administrators, managers, doctors and science workers; 34 of them assess their profes- sion as risky and 56 as not risky. The results support the hypothesis regarding significant positive correlations between well-being and life satisfaction, well-being and happiness, and negative correlation between well-being and stress. It was found that respondents who live with a partner are more satisfied with their life than the ones who live alone. No significant differences were registered in the assessment of subjective perception depending on the type of profession - risky or not risky.

Another study by Vasudev and Shastri (2017) examined the efficacy of hands-on reiki on perceived stress and subjective well-being among software professionals. A total of 60 software professionals from a software firm situated at Bangalore, India who met the inclusion exclusion criteria were taken up for the study. Sample was divided into two groups: experimental and control group (30 in each group). The intervention was carried out for 21 days for the experimental group and the control group was not given any intervention. Both groups were assessed at two time intervals, pre- and postassessment. Results of the study reveal that there is significant reduction in perceived stress and enhancement in subjective well-being from preto post- assessments in the intervention group. 
Furthermore, Kyzka, and Przybyia-Basista (2016) investigated the relationship between perceived stress and psychological well-being among parents of children with Down syndrome. The sample consisted of 126 parents ( 75 mothers and 51 fathers, aged 25-69) of children with Down syndrome. Results show that ego resiliency is a partial mediator of the relationship between perceived stress and psychological wellbeing. Moreover, there is a difference in wellbeing between parents who perceive their parenthood as a burden or challenge, and parents who report happiness and satisfaction (Relojo et al., 2018). Social support is emotional and instrumental assistance from family, friends or neighbours, and has an important but different impact on individuals, mainly depending on contextual factors. Yasin and Dzulkifli (2010) stated that social support may come from different sources such as family, friends, teachers, community, or any social groups to which one is affiliated. They further explained that social support can come in form of tangible assistance provided by others when needed which includes appraisal of different situations, effective coping strategies, and emotional support. Kamaliya (2017) explored the relation between social support's facets and subjective well-being's facets (i.e., life satisfaction, positive affect, and negative affect) in poor woman, specifically in PKH's (Program Keluarga Harapan) donation centre in Karangbesuki district on Malang City with research population of 92 people. Research method that is employed is quantitative approach.

Brajša-Žganec and Lipovčan (2018) examined how social support measured as the subjective assessment of social support adequacy given by family, friends or significant others contribute to well-being (happiness, life satisfaction and domain satisfactions) across the lifespan. The study was conducted on a representative sample of the Croatian adult population $(N=1.000)$. The results were analysed by means of multiple group structural equation modelling, which was performed separately for two measures of subjective well-being (SWB, which is a general measure of life satisfaction and happiness; and, PWI which covers domain satisfactions). The results showed that in all three age groups, among three sources of social support only the perceived social support from friends was significantly related to both subjective well-being measures. Participants who perceived adequate social support from friends expressed higher levels of subjective well-being.
Additionally, Nabulsi (2015) seek to determine if high levels of access to social support from family, friends and significant other along with high levels of mindfulness ability also known as calm (Relojo-Howell, 2019), conscious awareness, can predict high levels of psychological well-being (emotional and cognitive satisfaction with one's life). Self-report questionnaires were administered online to a sample of 889 students at the United Arab Emirates University. The findings showed that both social support scores and mindfulness scores significantly predicted subjective well-being scores. Social support was a stronger predictor of life satisfaction (the cognitive component of subjective well-being) than mindfulness. Whereas mindfulness was the strongest predictor of the positive affect scores, which is one of the emotional components of subjective well-being along with negative affect. Social support from family members was the highest source of social support when compared to social support from friends and significant other. The findings from this study can help guide clinical interventions in a more targeted, culturally sensitive and, therefore, more effective manner to increase subjective well-being in the UAEU student population. It is therefore imperative to look into the issue concerning the perceived stress and social support on subjective well-being of university students, and to ascertain those factors that can either improve or hinder its development. It is against this background that the authors aims to investigate the influence of perceived stress and social support on subjective well-being.

Students in higher educational institutions are viewed as leaders of tomorrow. They have academic success as their major goal. For this goal to be achieved, it requires dedication, sacrifices, self-discipline (Bautista et al., 2018), motivation and cordial relationship between students and lecturers. Students at this level are saddled with a lot of responsibilities and challenges (Imonikebe, 2009) which may sometimes result in stress. They need good mental health to be able to succeed in their academic pursuit.

Specifically, the study sought to: (1) investigate the influence of perceived stress on subjective well-being among university students of Benue State University; (2) examine the influence of social support on subjective wellbeing among university students; and, (3) establish the joint influence of perceived stress and social support on subjective well-being. Additio- 
nally, three hypotheses were proposed for this study: (1) Perceived stress will significantly predict subjective well-being among university students; (2) Social support will significantly predict subjective well-being; and, (3) Perceived stress and social support will significantly jointly predict subjective well-being.

\section{Methods}

Design

This study is cross-sectional survey design in which students' views and feelings about perceived stress, social support and subjective wellbeing was collected using questionnaires.

\section{Setting}

The area to which this study was carried out was at Benue State University Makurdi (BSU). Benue state university is located in Makurdi, Benue state. The university was founded in 1992 and is accredited by the National Universities Commission.

\section{Participants}

$194(65.1 \%)$ were male students while 104 $(34.9 \%)$ were female, while $2(2 \%)$ did not indicate, in terms of their age, $151(50.3 \%)$ aged between 18-22, 75 (25.0\%) were between the age of $23-27,46(15.3 \%)$ aged between $28-32$, while $28(9.3 \%)$ were between the ages of 3337. 400 level students were $112(37.3 \%), 72$ $(24.0 \%)$ were $3001,63(21.0 \%)$ were 2001 while 1001 were $53(17.7 \%)$. Considering their ethnicity, $122(40.7 \%)$ were Tiv, 104 (34.7) were Idoma, $47(15.7 \%)$ were Igede, $10(3.3 \%)$ were Hausa while 17 (5.3\%) were Igbo. 203 (67.7\%) students were UTME and 97 (32.3\%) were direct entry students.

\section{Sampling}

The convenient sampling technique was used for the study. This is a form of sampling whereby the researcher selects participants based on availability and convenience.

\section{Instruments}

Perceived Stress Scale (PSS). The Perceived Stress Scale (PSS) is the most widely used psychological instrument for measuring the perception of stress developed by Cohen et al. (1983). It is a measure of the degree to which situations in one's life are appraised as stressful. Items were designed to tap how unpredictable, uncontrollable, and overloaded respondents find their lives.

Social Support Scale (SSS). This is a 12-item measure of perceptions of social support. This measure is a shortened version of the original ISEL 40 items (Cohen \& Hoberman, 1983). This questionnaire has three different subscales desig- ned to measure three dimensions of perceived social support. These dimensions are, Appraisal Support, Belonging Support and Tangible Support. Each dimension is measured by four items on a four-point scale ranging from 'definitely true' to 'definitely false'. The test has internal reliability coefficient of .86 .

The Satisfaction with Life Scale (SWLS). The SWLS is a short five-item instrument designed to measure subjective well-being. The Satisfaction with Life Scale (SWLS) has been used heavily as a measure of the life satisfaction component of subjective well-being. The SWLS is a 7 -point Likert style response scale. The coefficient alpha for the scale has ranged from .79 to .89 , indicating that the scale has high internal consistency.

\section{Procedure}

Administration of questionnaires was done after informed consent were sought and granted from the participants. This was done in line with ethical principles of research in psychology. Both scales were self-explanatory, however if clarifications were needed, they were given at that time or later when the need arose. The scales were self-administered and completed at respondents' leisure. Some were collected at the time of meeting, while others later after the participant had completed them. Where and when the participants needed clarifications they were given. Descriptive statistics involving frequencies, mean and standard deviation were used to summarize the demographic data of the respondents. On the other hand, inferential statistics involving multiple regression and independent $t$-test were used in testing the hypotheses. Simple was used to test hypotheses one while, hypothesis three was tested using multiple linear regression.

\section{Results}

The result in Table 1 indicated that there was a significant influence of perceived stress on subjective well-being, $F(1,193)=2.084$, $p<.004$. The result further sows that perceived stress accounted for $4.2 \%$ of the variance in subjective well-being. Based on this finding, Hypothesis 1 was accepted.

The result in $\boldsymbol{T a b l e} \mathbf{2}$ revealed that there is no significant influence of social support on subjective well-being $[F(1,293)=.003, p>.05]$. Based on this finding, Hypothesis 2 was rejected.

The result in $\boldsymbol{T a b l e} \mathbf{3}$ shows that there is no significant joint influence of perceived stress and social support on subjective well-being, $F(2,283)=1.214, p>.05$. With this result, Hypothesis 3 was not confirmed. 
Simple Linear Regression Showing the Influence of Perceived Stress on Subjective Well-being

\begin{tabular}{clllllll}
\hline Variable & $\boldsymbol{R}$ & $\boldsymbol{R}^{2}$ & $\boldsymbol{d} \boldsymbol{f}$ & $\boldsymbol{F}$ & $\boldsymbol{\beta}$ & $\boldsymbol{t}$ & Sig. \\
\hline Constant & .084 & .042 & 1.293 & 2.084 & & 5.038 & $*$ \\
Perceived stress & & & & .084 & 1.444 & $* *$ \\
\hline
\end{tabular}

$* p<.01, * * p<.05$

Table 2

Simple Linear Regression Showing the Influence of Social Support on Subjective Well-being

\begin{tabular}{cccccccc}
\hline Variable & $\boldsymbol{R}$ & $\boldsymbol{R}^{2}$ & $\boldsymbol{d} \boldsymbol{f}$ & $\boldsymbol{F}$ & $\boldsymbol{\beta}$ & $\boldsymbol{t}$ & Sig. \\
\hline Constant & .003 & .000 & 1,293 & .003 & & 10.274 & $*$ \\
Social support & & & & & -.003 & -.057 & $* *$ \\
\hline
\end{tabular}

$* p<.01, * * p<.05$

Multiple Linear Regression Showing the Joint Influence of Perceived Stress

Table 3 and Social Support on Subjective Well-being

\begin{tabular}{llllllll}
\hline Variables & $\boldsymbol{R}$ & $\boldsymbol{R}^{2}$ & $\boldsymbol{d} \boldsymbol{f}$ & $\boldsymbol{F}$ & $\boldsymbol{\beta}$ & $\boldsymbol{t}$ & Sig. \\
\hline Constant & .091 & .008 & 2,293 & 1.214 & & 2.887 & $*$ \\
Perceived social support & & & & .100 & 1.557 & $*$ \\
Social support & & & & .038 & .590 & $*$ \\
\hline
\end{tabular}

$* p<.01$

\section{Discussion}

First hypothesis sought to establish if perceived stress will significantly influence subjective well-being. The finding of this hypothesis turns out to be true. This means that the feelings or thoughts the students have about how much stress they are under at a given point in time or over a given time period can have influence on their subjective well-being. The result further shows that $4.2 \%$ of the variance in psychological among university students is accounted for by perceived stress. This result is in line with Vasudev and Shastri (2017) who reported that a significant reduction in perceived stress resulted to enhancement in subjective well-being from preto post- assessments in the intervention group. The finding is also consistent with Kyzka and Przybyia-Basista (2016) who in their study on the relationship between perceived stress and psychological well-being among parents of children with Down syndrome, found that there is a difference in well-being between parents who perceive their parenthood as a burden or challenge, and parents who report happiness and satisfaction. The present study also agreed with several other studies that there is a significant relationship between perceived stress and subjective well-being (Denovan \& Macaskill, 2018; Zarbova \& Karabeliova, 2018).

Hypothesis 2 stated that there will be a significant influence of social support on subjective well-being was not confirmed. This implies that social support does not have a significant impact on subjective well-being. However, this result disagreed with Kamaliya (2017) who reported that there is a positive relationship between social support and subjective well-being. Also, this result is not consistent with HsingMing et al. (2017) who researched on the influence of preschool teachers' social support on subjective well-being (SWB), and age's moderation effect on this relationship and reported that preschool teachers' social support has positive influence on SWB, that the more preschool teachers obtain social support, the higher SWB will be. Similarly, the finding of this study had failed to agree with Brajša-Žganec and Lipovčan (2018) who had reported that all three age groups, among three sources of social support only the perceived social support from friends was significantly related to both subjective wellbeing measures. 
Again, it was hypothesised that there will be a significant joint influence of perceived stress and social support on subjective well-being among university students. This hypothesis was tested and the result indicated that there is no significant joint influence of perceived stress and social support on subjective well-being. This implies that though perceived stress can predict subjective well-being on its own, but when combined with social support they both failed stir up a significant change in subjective wellbeing. With this result, Hypothesis 3 was not confirmed.

\section{Conclusion}

There is a significant influence of perceived stress on subjective well-being, while there is no significant influence of social support on subjective well-being. Meanwhile, there is no significant joint influence of perceived stress and social support subjective well-being.

University students in all universities either government owned or private owned should be assessed and those with high score on perceived stress should be giving intervention to increase their subjective well-being. Also, social support from parent, guardians, staff and colleague should be encouraged among university students and the entire university system at large.

\section{REFERENCES}

Bautista, L., Relojo, D., Pilao, S.J., Tubon, G., \& Andal, M. (2018). Link between lifestyle and self-regulated development as components of academic performance: Basis for a psychoeducational intervention. Journal on Educational Sciences \& Psychology, 8(52), 68-72. https:// doi.org/10.5281/zenodo.1258146

Brajša-Žganec A., Kaliterna-Lipovčan, L., \& Hanzec, I. (2018). The relationship between social support and subjective well-being across the lifespan. Društvena Istraživanja, 27(1), 47-45. https://doi.org/10.5559/ di.27.1.03

Cohen, S., \& Hoberman, H. M. (1983). Positive events and social supports as buffers of life change stress 1. Journal of Applied Social Psychology, 13(2), 99-125. https:// doi.org/10.1111/j.1559-1816.1983.tb02325.x

Cohen, S., Kamarck, T., \& Mermelstein, R. (1983). A global measure of perceived stress. Journal of Health and Social Behavior, 24(4) 385-396. https://doi.org/10.2307/ 2136404

Denovan, A. \& Macaskill, A. (2018). Stress and subjective well-being among first year UK undergraduate students. Journal of Happiness Studies, 12(2) 23-34. https:/ /doi.org/10.1007/s10902-016-9736-y

Diener, E. (1984). Subjective well-being. Psychological
Bulletin, 95(3), 542-575. https://doi.org/10.1037//00332909.95.3.542

Hsing-Ming, L., Mei-Ju, C., Chun-Ho, C. \& Ho-Tang, W. (2017). The relationship between social support and subjective well-being of preschool teachers: take age as the moderator variable. European Journal of Research and Reflection in Educational Sciences, 5(5), 891-900. https:// doi.org/10.13189/ujer.2017.050521

Imonikebe, B. U. (2009). Strategies for promoting the nutritional and health status of students in higher institution of learning in Nigeria for sustainable national development. $4^{\text {th }}$ Regional Conference of Higher Education for Sustainable Development in Africa.

Kamaliya, N. (2017). The relationship between social support and subjective well-being on women in poverty. UI Proceedings on Social Science and Humanities, 1.

Kyzka, A., \& Przybyia-Basista, H. (2016). The relationships between perceived stress and psychological well-being among mothers and fathers of children with Down syndrome. The New Educational Review, 44(2), 285-294. https://doi.org/10.15804/tner.2016.44.2.23

Nabulsi, S.E (2015). Predicting subjective well-being using social support and mindfulness for United Arab Emirates University students (Unpublished undergraduate thesis). United Arab Emirates University.

Relojo, D. \& dela Rosa, R. (2017). Improving positive affect based on self-compassion through life goals expressive writing: Basis for an ego identity development among students. Problems of Psychology in the 21st Century, 11(1), 51-58. https://doi.org/10.5281/ zenodo.1289161

Relojo, D., Santos, A., \& Borlongan, A. (2018). A prospective study on the bidirectional association between parenting styles and self-regulation among university students. Journal of Innovation in Psychology, Education and Didactics, 22(1), 63-76. https://doi.org/10.5281/ zenodo. 1620990

Relojo-Howell, D. (2019, March 11). Student mental health: Can mindfulness reduce stress. Retrieved from https://welldoing.org/article/student-mental-healthmindfulness-stress

Vasudev, S.S \& Shastri, S. (2017). Effect of hands on reiki on perceived stress and subjective wellbeing among software professionals in Bangalore. International Journal of Social Science and Humanity, 2(6), 720-727. https:// doi.org/10.18769/ijasos.280373

Wilson, W. R. (1967). Correlates of avowed happiness. Psychological Bulletin, 67(4), 294-306. https://doi.org/ 10.1037/h0024431

Yasin, A. S., \& Dzulkifli, M. A. (2010). The relationship between social support and psychological problems among students. International Journal of Business and Social Science, 1(3). 110-116.

Zarbova, B. \& Karabeliova, S. (2018). Stress and wellbeing. 12th International Conference Days of Applied Psychology 2016 "Contemporary Psychology and Practice", University of Nish, Serbia. 


\section{АНОТАЦІЯ}

Отвуче Чінело Хелен, Калеб Она, Релоджо-Говел Денніс. Сприйняття стресу і соціальної підтримки як показники суб'єктивного благополуччя серед студентів університету Нігерії.

У поданій статті вивчено вплив сприйняття стресу та своєчасної соціальної підтримки під час його переживання як показників суб'єктивного благополуччя серед студентів Бенуеського державного університету в Нігерії. Для цього дослідження було створено програму міжсекторального (перехресного) опитування. Ії реалізація стала можливою завдяки 300 учасникам віком від 18 до 37 років, які були відібрані з допомогою зручного методу вибірки. Для збору даних в емпіричному дослідженні були використані Шкала сприйняття стресу (PSS), Шкала соціальної підтримки (SSS) та Шкала задоволеності життям (SWLS). Було сформульовано три гіпотези та проведено аналіз даних $з$ використанням простих лінійних і множинних регресійних аналітичних процедур. Гіпотеза 1 була прийнята $[\mathrm{F}(1,193)=2,084, \mathrm{P}<.004]$, гіпотезу 2 було відхилено [ $\mathrm{F}(1,293)=.003, \mathrm{P}>.05]$, натомість гіпотезу 3 не було підтверджено [F $(2,283)=1,214, \mathrm{P}>.05]$. Встановлено, що значний вплив на суб'єктивне відчуття щастя серед студентів університету має сприйняття стресу, в той час як істотної дії соціальної підтримки на суб'єктивне благополуччя не виявлено. Нарешті, не встановлено значного спільного впливу сприйняття стресу та соціальної підтримки на суб'єктивне благополуччя. Рекомендується оцінювати студентів університету і допомагати тим, хто має високий бал сприйняття стресу в напрямку підвищення їхнього суб'єктивного самопочуття, а також треба заохочувати соціальну підтримку батьків, опікунів, співробітників та колег задля поліпшення персонального благополуччя студентів університету і всієї психосоціальної системи університетської освіти загалом.

Ключові слова: студент як суб'єкт повсякдення, психічне здоров'я; сприйняття стресу; соціальна підтримка, опитування, студенти університету; суб'єктивне благополуччя
ANNOTATION

Chinelo Helen Ogwuche, Onah Caleb, Dennis RelojoHowell.

Perceived stress and social support as predictors of subjective well-being among university students in Nigeria.

This study investigated the influence of perceived stress and social support as predictors of subjective well-being among university students of Benue State University in Nigeria. The cross-sectional survey design was adopted for this study as 300 participants were selected using the convenient sampling technique with their age range from 18-37 years old. The Perceived Stress Scale (PSS), Social Support Scale (SSS) and the Satisfaction with Life Scale (SWLS) were used for collecting data for the study. Three hypotheses were stated and data analysis was carried out using the simple linear and multiple regression analyses. Hypothesis 1 was accepted $[\mathrm{F}(1,193)=2.084, \mathrm{P}<.004]$. Hypothesis 2 was rejected $[\mathrm{F}(1,293)=.003, \mathrm{P}>.05]$. Finally, Hypothesis 3 was not confirmed $[\mathrm{F}(2,283)=1.214, \mathrm{P}>.05]$. There is a significant influence of perceived stress on subjective well-being among university students, while there is no significant influence of social support on subjective well-being. Finally, there is no significant joint influence of perceived stress and social support subjective well-being. It is recommended that university students should be assessed and those with high score on perceived stress should be given intervention to increase their subjective well-being also, social support from parent, guardians, staff and colleagues should be encouraged among university students and the entire university system at large.

Keywords: mental health; perceived stress; social support; university students; well-being. д. психол. н., проф., Болтівець С.І. д. психол. н., проф., Фурман О.Є.

Надійшла до редакції 05.12.2019. Підписана до друку 28.12.2019.

Бібліографічний опис для цитування:

Ogwuche C.H., Caleb O., Relojo-Howell D. Perceived stress and social support as predictors of subjective well-being among university students in Nigeria. Психологія і суспільство. 2020. №1. C. 120-125. DOI: https://doi.org/10.35774/pis2020.01.120 